Revised: July 1981

AN INTERNATIONAL COMPARISON OF THE

PRICE OF NONTRADED GOODS*

by

Kenneth W. Clements .

The University of Western Australia

and

Muthi Semudram

National University of Singapore

\title{
Abstract
}

Balassa (1964) argues that purchasing power parity calculations are subject to a productivity bias as nontraded goods are relatively more expensive in high income countries. An analysis of three independent sets of data gives strong support to this argument.

* We are indebted to Victor Argy, Larry Officer, Bill Norton, Kim Sawyer and Les Stein for helpful comments, and to Rossi Centenera of Qantas Airways for clarification of the data used in this paper. 
AN INTERNATIONAL COMPARISON OF THE

PRICE OF NONTRADED GOODS

Kenneth $W$. Clements

The University of Western Australia

and

Muthi Semudram

National. University of Singapore

Discussion Paper 81.15

September 1981 
Balassa (1964) argues that purchasing power parity calculations are subject to a productivity bias as nontraded goods are relatively more expensive in high income countries. The objective of this note is to analyse three sets of data to test whether or not the price of nontraded goods does display this type of behavior. We first use the price of haircuts, which can be viewed as a classic nontraded good (Samuelson, 1964 p. 148). We then use the Kravis et al. (1978) data on prices of consumer goods in fifteen countries. The final set of data refer to the movement over time of the relative price of nontraded goods in each of nine countries. All the results give strong support to the Balassa hypothesis. Before turning to the results we first give an exposition of Balassa's analysis of nontraded goods and the exchange rate.

\section{Nontraded Goods and the Exchange Rate}

Balassa (1964) argues that relative to a low productivity (poor) country, in a high productivity (rich) country the price of nontraded goods in terms of traded will be lower, due to productivity differences being more pronounced in the traded goods sector. He further argues that, because the price of nontraded goods is not directly relevant for exchange rate determination, the purchasing power parity (PPP) based on general price levels (which include both traded and nontraded goods) will be systematically biassed in relation to the actual exchange rate.

In the right panel of Fig. $1 \mathrm{P}_{\mathrm{T}}$ and $\mathrm{P}_{\mathrm{N}}$ are the prices of traded and nontraded goods. The relative price for the poor country is $\alpha_{p}$ which is given by the slope of the ray from the origin ${ }_{\mathrm{p}}^{\mathrm{O}} \cdot{ }_{\text {. The }}$ price level is held constant along the curve $A A$, which gives the various combinations of $\mathrm{P}_{\mathrm{T}^{\prime}} \mathrm{P}_{\mathrm{N}}$ consistent with that price level. The schedule is negatively sloped because a higher $\mathrm{P}_{\mathrm{T}}$ must be compensated by a lower $\mathrm{P}_{\mathrm{N}}$ in order to keep the overall price level constant. We call AA the absolute price schedule. For the real economy to be in equilibrium, it must be located 
somewhere on $\mathrm{OR}_{\mathrm{p}}$; for monetary equilibrium we must be on $\mathrm{AA}$. It is clear that only $E_{p}$ satisfies both requirements simultaneously, so that this is the point of overall equilibrium with $\mathrm{P}_{\mathrm{Tp}}$ the nominal price of traded goods.

The left panel of Fig. 1 applies PPP to the traded goods.

The poor country's exchange rate $s_{p}$ (the price of foreign currency in terins of domestic currency) is given by the slope of the ray from the origin passing through the point $\mathrm{P}_{\mathrm{Tp}_{\mathrm{p}}} \mathrm{P}_{\mathrm{TO}}^{*}$ where $\mathrm{P}_{\mathrm{TO}}^{*}$ is the foreign price of traded goods. 1

In the rich country the relative price of traded goods $\alpha_{r}$ is lower than that in the poor country. In Fig. I to isolate the effects of differing relative price structures, both countries share the same absolute price schedule $A A$. The equilibrium for the rich country is $E_{r}$ with exchange rate $s_{r}$. By construction, the price level in the two countries is the same so that PPP based on these price Ievels indicates that the two excharge rates should also be the same. Since the actual exchange rate for the rich country is lower than that for the poor $\left(S_{r}<S_{p}\right.$ ), the conclusion is that this type of PPP calculation indicates that the rich country's currency is overvalued. This result is known as the productivity bias in PPP.

\section{The Price of a Haircut in 24 Countries}

In this section we use the price of a haircut to measure the price of nontraded goods. Being a personal service, haircuts obviously cannot be easily traded internationally so that their price should be'a good proxy for that of nontraded goods. If this is the case, then expressing the price of haircuts in different countries in terms of a common currency gives a measure interpreted as the price of nontraded goods in terms of traded. To see this, apply PPP to traded goods to give $\mathrm{P}_{\mathrm{T}}=\mathrm{S} . \mathrm{P}_{\mathrm{T}}^{*}$, so that the relative price of nontraded goods is $\mathrm{P}_{\mathrm{N}} / \mathrm{P}_{\mathrm{T}}=\mathrm{P}_{\mathrm{N}} / \mathrm{S} . \mathrm{P}_{\mathrm{T}}^{*}$; choosing 
units such that $\mathrm{P}_{\mathrm{T}}^{*}=1$ gives $\mathrm{P}_{\mathrm{N}} / \mathrm{P}_{\mathrm{T}}=\mathrm{P}_{\mathrm{N}} / \mathrm{S}$, which is the price of nontraded goods in terms of foreign currency.

Table 1 gives the price of a haircut in us dollars for 24 countries and real per capita GDP, our measure of productivity (income) ${ }^{2}$ The haircut data refer to prices at major tourist hotels, which means that we are comparing more or less the same type of service across countries. This also means that there would be at least some tendency for the price to be equalized across countries due to tourism.

TABLE 1

PRICE OF A HAIRCUT AND REAL PER CAPITA GDP FOR 24 COUNTRIES IN 1979

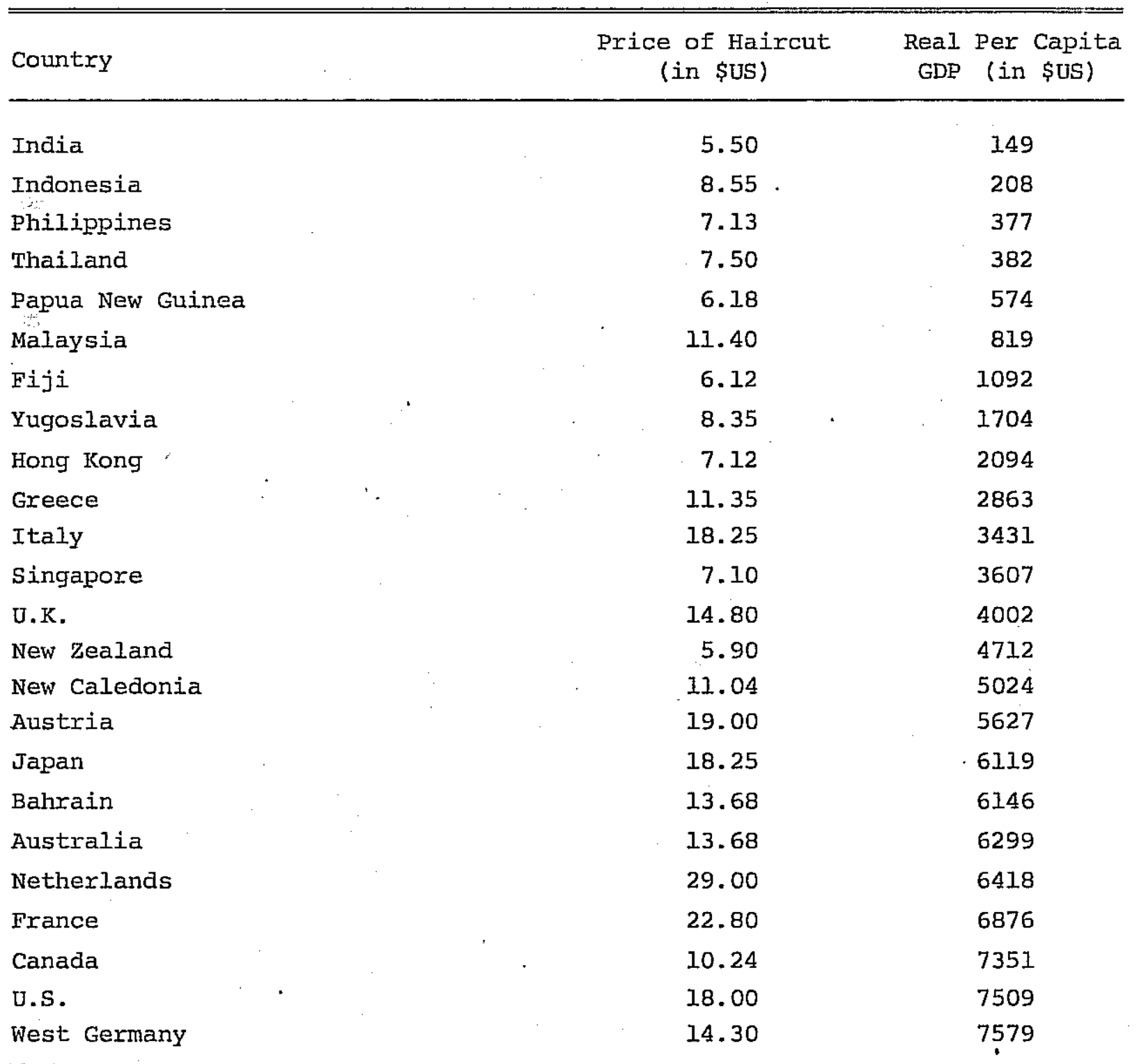

The price of a haircut refers to the average cost of a salon shampoo and set for a woman, from QANTAS, It's a Woman's World, 1979 (travel brochure). Real per capita GDP in 1979 is the projected value based or he actual real per capita GDP in 1974 and its growth rate between 1965-197 : From World Bank Atzas. 
There is a clear positive association between the price of a haircut and GDP; the rank correlation coefficient is ..66. Using the Table 1 data to regress the price on GNP gives (standard errors are given in parentheses):

$$
\begin{aligned}
\log \left(\mathrm{P}_{\mathrm{N}} / \mathrm{P}_{\mathrm{T}}\right) & =\underset{(.476)}{.417}+\underset{(.061)}{.256 \log \mathrm{GDP}} \\
\mathrm{R}^{2} & =.45 \quad \mathrm{DW}=2.17 .^{3}
\end{aligned}
$$

The income elasticity of the relative price of nontraded goods is .26 and highly significant. The above-mentioned tendency for the price of a haircut to be equalized across countries has the effect of biassing this elasticity toward zero, 4 so that our estimate represents a lower bound to the true elasticity. This finding therefore gives strong support to Balassa's argument that nontraded goods are relatively more expensive. in high income countries.

\section{A Multi-Comodity Analysis}

Voltaire and Stack (1980) use the international consumption data assembled by Kravis et al. (1978) to analyse how relative consumer prices move with real income per capita. The data refer to 16 countries in 1970 , but voltaire and Stack delete one country (Kenya) as it is an outlier. 5 They also aggregate the data into eight broad groups and their results are summaried in Table 2 .

The largest negative relative price elasticity is for food, while recreation has the largest positive elasticity. Thus, as we move Erom poor to richer countries, food becomes cheaper relative to recreation. It seems reasonable to suppose that food is internationally traded, while recreation (which includes education) has a large service component which tends to make it a nontraded good. These results therefore confirm our previous finding that nontraded goods are relatively more expensive in rich countries. Moreover; the size of these two elasticities (.38 for the 
nontraded goods and -.21 for traded) is highly consistent with the result of equation (1).

TABI.E 2

INCOME ELASTICITIES OF' RELATIVE PRICES

\begin{tabular}{lc}
\hline Good & $\begin{array}{c}\text { Elasticity of } \\
\text { relative price } \\
\text { with respect to real } \\
\text { income per capita }\end{array}$ \\
\hline Food & -.21 \\
Clothing & .04 \\
Rent & -.05 \\
Furniture & .11 \\
Medical care & .26 \\
Transport & .07 \\
Recreation & .38 \\
Other expenditure & .11 \\
\hline
\end{tabular}

Source: Voltaire and stack (1980)

The results of Table 2 also indicate that medical care is relatively more expensive in rich countries. This also supports the Balassa hypothesis since medical care comprises mainly of personal services and is hence a nontraded good. Rent has an elasticity of about zero, which is somewhat unexpected as housing is generally thought of as a nontraded good. The explanation for this finding is that this group is not all housing rent, but also includes fuel, a traded good.

4. An Analysis of the Relative Price of Nontraded Goods Over Time in Nine Countries

Goldstein and officer (1979) use GDP by industry of origin to classify the total into traded and nontraded goods and form price indexes as ratios of current to constant price output. They allocate to traded goods (i) agriculture and related activities, (ii) mining and quarrying and 
(iii) manufacturing; everything else is nontraded (mainly services, construction ard government).

Goldstein and Officer construct time series data for $\mathrm{P}_{\mathrm{N}} / \mathrm{P}_{\mathrm{T}}$ for nine countries. We use these data to analyse the relationship between the relative price and per capita gross domestic product within each country through time. The results are given in Table 3 .

\section{TABLE 3}

REGRESSION RESULTS: ANNUAL DATA FOR NINE COUNTRIES

$$
\log \left(P_{\mathrm{N}} / \mathrm{P}_{\mathrm{T}}\right)_{\mathrm{t}}=\alpha+\beta \log \mathrm{GDP} \mathrm{t}_{\mathrm{t}}+\varepsilon_{\mathrm{t}}
$$

(Standard errors in parentheses)

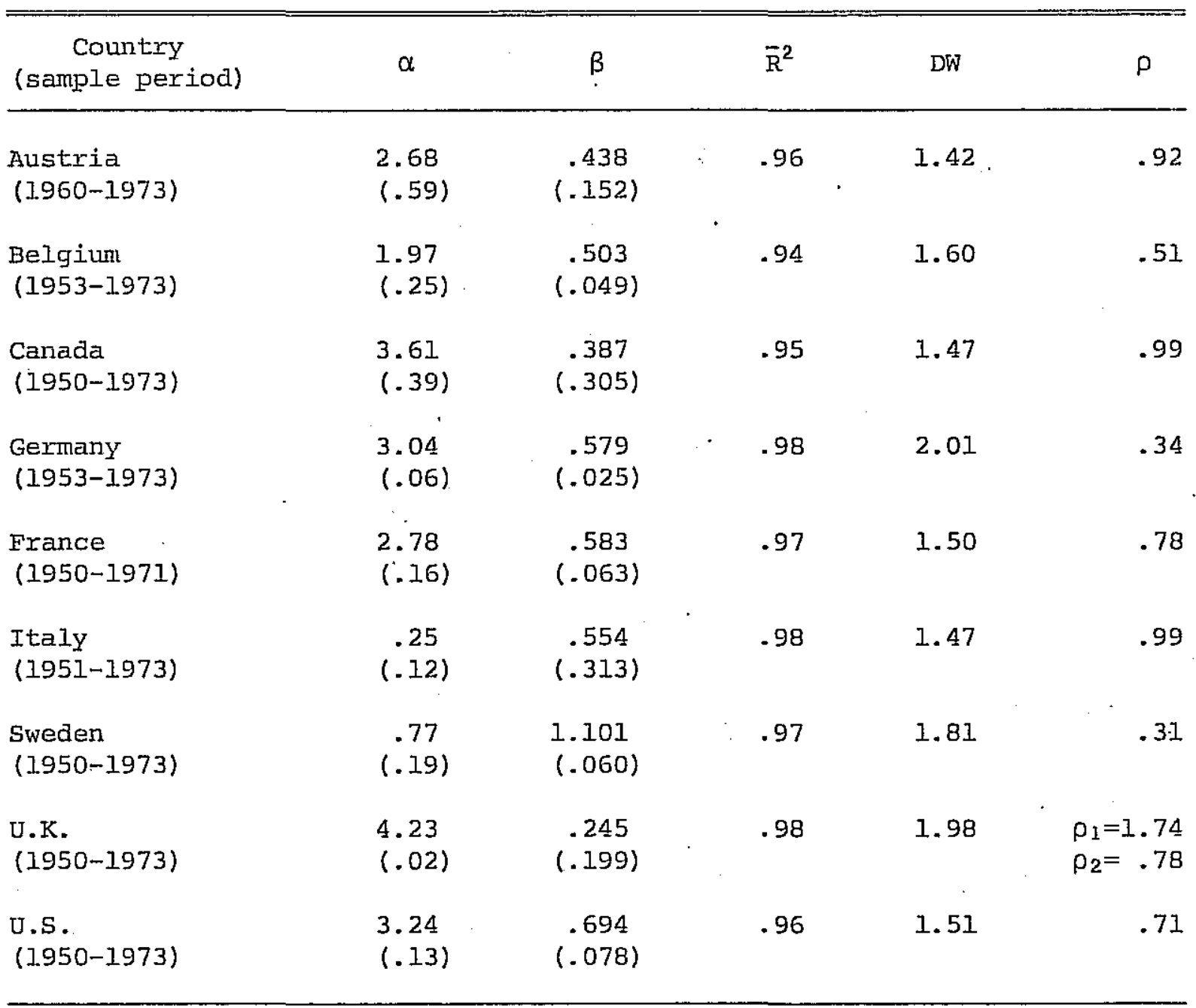

The variable $\mathrm{P}_{\mathrm{N}} / \mathrm{P}_{\mathrm{T}}$ is the ratio of the price index of nontraded goods to that of traded goods, from Goldstein and Officer (1979). GDP is real per capita gross domestic product, from International Monetary Fund, IFS. The equations are estimated by the Cochrane-Orcutt procedure which adjusts for first-order residual autocorrelation; $\rho$ is the autocorrelation coefficient. For the U.K. the residual follows an AR2 process. 
As can be seen, in all nine countries the income elasticity of ${ }_{\mathrm{N}} / \mathrm{P}_{\mathrm{T}}$ is positive and generally highly significant. In all cases except Sweden the elasticity is less than one, with an average value of .56. Again the result is that nontraded goods become relatively more expensive with increasing per capita income. In relation to the previous cross-sectional results, these elasticities are somewhat higher, but not substantially.

\section{Concluding Comments}

Using three sets of data, we have clearly shown that nontraded goods become relatively more expensive as income rises, which gives strong support to the Balassa hypothesis. Using both cross-sectional and time series data, we established that the income elasticity of the relative price of nontraded goods is positive and in most cases highly significant. our results imply that for rich countries the exchange rate is systematically below PPP calculations based on general price levels. I.e. this version of PPP will indicate (erroneously!) that the currencies of the rich countries are overvalued.

In a recent paper; officer (1976, Sec. II) also examines the relationship between the price of nontraded goods and income across countries. Using a quite limited sample of countries, his results are mixed. In contrast, our findings give uniformly positive support to the Balassa hypothesis. 
FOOTNOTES

1. For a further analysis of the workings of Fig. 1, see Clements (1980).

2. Balassa and others have also used GDP per capita as a measure of productivity.

3. An analysis of the residuals indicates that New Zealand and the Netherlands are outliers; none of the qualitative results change when these observations are omitted. Using the Box-Cox (1964) transformation as a check on the functional form, we cannot reject the double-log specification.

4. To see this, consider the extreme case of complete equalisation; then the price would be independent of income.

5. The countries are India, Korea, Philippines, Malaysia, Colombia, Iran, Hungary, Italy, Japan, Netherlands, U.K., West Germany, France, Belgium and U.S. 
REFERENCES

Balassa, B. (1964). "The Purchasing Power Parity Doctrine: A Reappraisal." Journal of Political Econony 72:584-96.

Box, G.E.P. and D.R. Cox (1964). "An Analysis of Transformations." Journal of the Royal Statistical Society Series B 26:211-43.

Clements, K.W. (1980). "The Monetary Approach to Exchange Rate Determination: A Geometric Analysis." Weltwirtschaftliches Archiv, forthcoming.

Goldstein, M. and I.H. Officer (1979). "New Measures of Prices and Productivity for Tradeable and Nontradeable Goods." Review of Income and Wealth 25:413-27.

Kravis, I.B., A.W. Heston and R. Sumers (1978). Intemational Comparisons of Real Product and Purchasing Power. Baltimore, Md: The Johns Hopkins University Press.

Officer, I.H. (1976). "The Productivity Bias in Purchasing Power Parity: An Econometric Investigation." International Monetary Fund Staff Papers 23:545-79.

Samuelson, P.A. (1964). "Theoretical Notes on Trade Problems." Review of Economics and Statistics :146-54.

Voltaire, K. and E.J. Stack (1980). "A Divisia Version of the Country-" Product-Dumny Method." E'conomics Letters 5:97-9. 


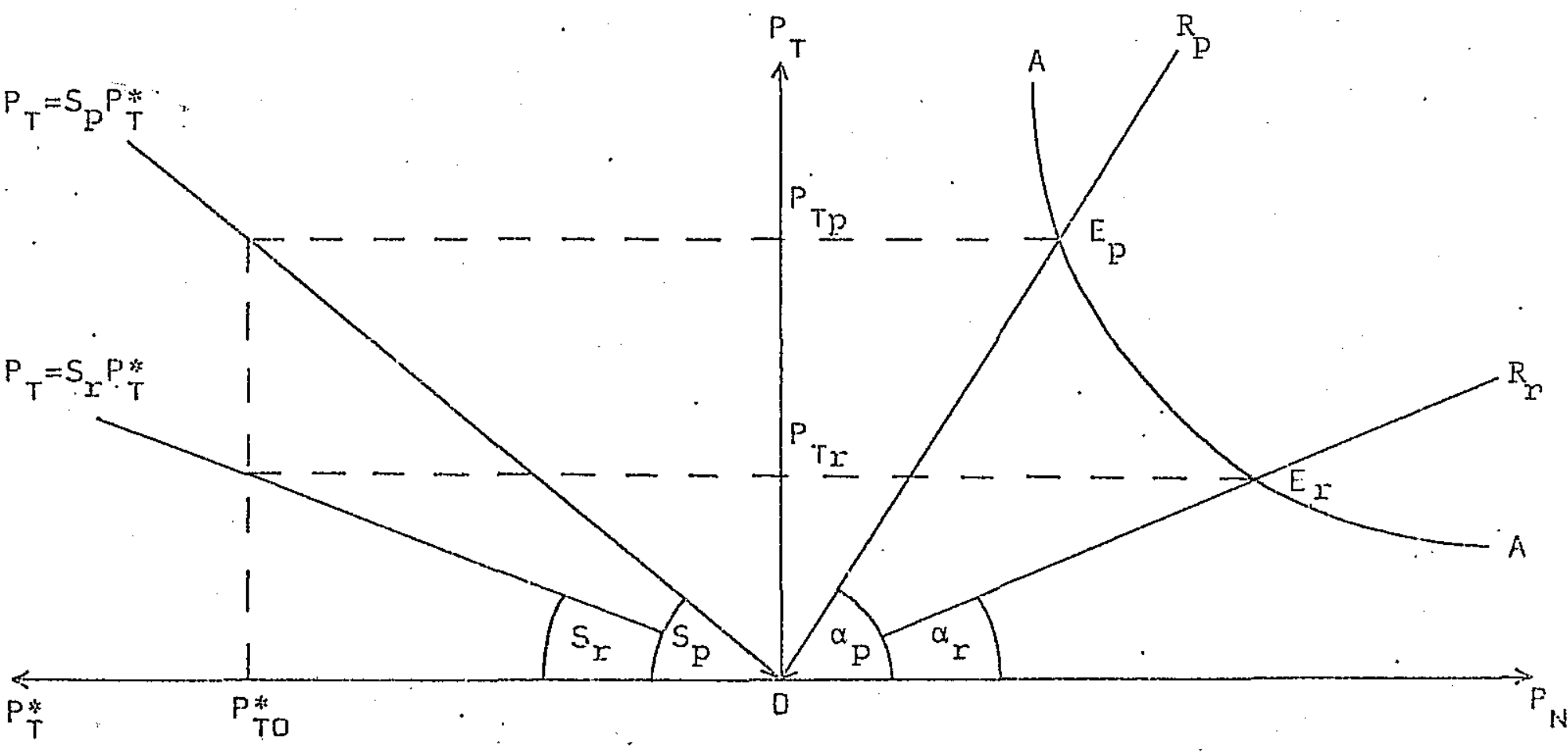

FI GURE I 